\title{
APPROXIMATE ESTIMATES OF THE TEMPERATURE STATE OF CERAMIC NUCLEAR FUEL IN CYLINDRICAL FUEL ELEMENTS AND THE INFLUENCE OF PROCESSES AND PARAMETERS OF A NUCLEAR REACTOR CORE
}

\begin{abstract}
The approximate mathematical model of the temperature state of ceramic nuclear fuels in cylindrical fuel elements was proposed in the form of linear ordinary differential equation and the boundary conditions. The theory of heat conduction and assumptions about the axial symmetry and absence of heat flows along axis of fuel element, which allow to simplify the common equations in cylindrical coordinates, are the basis of the proposed simplified mathematical model for approximate estimating the temperature state of the nuclear fuel. The intensity of volume heat sources in fuel element was taken into account by using the average values corresponding with the heat power and the structural characteristics of a nuclear reactor core. The conception about the heat transfer coefficient was used for modeling interaction between the fuel and the heat carrier. This heat transfer coefficient depends on characteristic sizes and heat conductions of constituted materials of the fuel element and allows to estimate influence of these on the temperature state of the nuclear fuel. The analytical solution for the temperature of a ceramic fuel in cylindrical fuel elements was obtained and was used for researching. It was shown that the heat conductivity of the fuel has significantly influences both the average temperature and the difference between the inner and outer temperatures in the fuel pellet. At the same time, other parameters have significant influence only on the average temperature of the fuel pellet. Due to these, it is necessary to consider the temperature dependence of the thermal conductivities of the materials constituted the fuel elements for more precisely estimations the temperature state of the fuel pellets, which will lead to nonlinear equations will required the numerical methods for their solving.

Key words: ceramic nuclear fuel, fuel elements, temperature state, volume heat sources, stationary thermal conductivity, thermal conductivity, heat transfer coefficient, heat transfer condition, boundary conditions, integration constants.
\end{abstract}

Ю. В. РОМАШОВ, Д. О. ЧІБІСОВ

НАБЛИЖЕНА ОЦІНКА ТЕМПЕРАТУРНОГО СТАНУ КЕРАМІЧНОГО ЯДЕРНОГО

ПАЛИВА В ЦИЛІНДРИЧНИХ ТВЕЛАХ ТА ВПЛИВУ НА НЬОГО ПРОЦЕСІВ І ПАРАМЕТРІВ КОНСТРУКЦЙ АКТИВНОЇ ЗОНИ РЕАКТОРА

На основі математичної моделі теплопровідності з урахуванням ряду гіпотез спрощення отримані наближені кількісні оцінки температурного стану керамічного ядерного палива в активній зоні ядерного енергетичного реактора. Досліджено вплив на температурний стан ядерного палива температури теплоносія, тепловіддачі від оболонки твела до теплоносія, теплопровідності оболонки, газового наповнювача твела, керамічного палива, а також розмірів палива. Показано, що теплопровідності палива і конструкційних матеріалів твела мають найбільший вплив на температурний стан керамічного ядерного палива.

Ключові слова: керамічне ядерне паливо, тепловиділяючі елементи, температурний стан, об'ємні джерела тепла, стаціонарна теплопровідність, коефіцієнт теплопровідності, коефіцієнт тепловіддачі, умова теплопередачі, граничні умови, сталі інтегрування.

\section{Ю. В. РОМАШОВ, Д. А. ЧИБИСОВ \\ ПРИБЛИЖЕННАЯ ОЦЕНКА ТЕМПЕРАТУРНОГО СОСТОЯНИЯ КЕРАМИЧЕСКОГО \\ ЯДЕРНОГО ТОПЛИВА В ЦИЛИНДРИЧЕСКИХ ТВЭЛАХ И ВЛИЯНИЯ НА НЕГО ПРОЦЕССОВ И ПАРАМЕТРОВ КОНСТРУКЦИЙ АКТИВНОЙ ЗОНЫ РЕАКТОРА}

На основе математической модели теплопроводности с учетом ряда упрощающих гипотез получены приближенные количественные оценки температурного состояния керамического ядерного топлива в активной зоне ядерного энергетического реактора. Исследовано влияние на температурное состояние ядерного топлива температуры теплоносителя, теплоотдачи от оболочки твэла к теплоносителю, теплопроводностей оболочки, газового наполнителя твэла, керамического топлива, а также размеров топлива. Показано, что теплопроводности топлива и конструкционных материалов твэла оказывают наибольшее влияние на температурное состояние керамического ядерного топлива.

Ключевые слова: керамическое ядерное топливо, тепловыделяющие элементы, температурное состояние, объемные источники тепла, стационарная теплопроводность, коэффициент теплопроводности, коэффициент теплоотдачи, условие теплопередачи, граничные условия, постоянные интегрирования.

\section{Introduction}

The operability of fuel elements of industrial nuclear reactors is primarily limited by the temperature state of their structural elements due to understandable natural causes, occurring from purposes of the fuel element and its operating conditions in a core of nuclear reactors.

Nuclear power reactors, using cylindrical fuel rods with ceramic nuclear fuel, are the most common in the world nuclear power industry at present, which is well-known $[1,2]$. The temperature state of struc- tural elements significantly limits the operability of cylindrical fuel rods [1-3]. Therefore the study of the fundamental regularities of the temperature state in fuel rods is of considerable interest for nuclear power industry and engineering. Taking into account the noted circumstances, it seems to be of current interests the theme of this article, in which approximate estimates were obtained and some fundamental regularities of the temperature state of ceramic nuclear fuel in cylindrical fuel elements were established. Obtained results can be used also for benchmarking the more complicated approaches [4].

(C) Yu. Romashov, D. Chibisov, 2019 


\section{Purposes of the article}

In cylindrical fuel rods of a widely-used design, the temperature state of a ceramic nuclear fuel is determined by several heat exchange processes, included the heat transfer between the fuel and the gas gap, the heat conductivity in the gas gap, the heat transfer from the gas gap to the shell, the thermal conductivity in the shell, and the heat transfer from the shell to the moving coolant. A reliable theoretical assessment of the temperature state of a ceramic nuclear fuel requires consideration of all heat exchange processes in a fuel element, which leads to the complicated mathematical models in general. At the same time, it is necessary to have the approximate quantitative assessments, which will allow to understand the general fundamental qualitative regularities of the temperature state of a ceramic nuclear fuel in fuel rods. Such approximate assessments must be based on the simplified mathematical models, providing opportunities for obtaining the exact analytical solutions, which will allow to use these approximate estimations for constructing and benchmarking the more complicated mathematical models will require the numerical methods. Thus, the purpose of this article is to build the simplified quantitative assessments of the temperature state of the ceramic nuclear fuel in cylindrical fuel rods for benchmarking further the results, based on the more complicated mathematical models.

\section{Mathematical model of heat conductivity for simplified assessments of temperature state}

The ceramic nuclear fuel, made as the pellets, is contained inside the cladding of the fuel element as shown on the fig. 1 . The length $L$ of the fuel element is significantly greater than the external radius $R_{c}$ of their cladding (fig. 1); the gap-2 between the fuel pellet- 1 and the internal surface of the cladding- 3 is filled by the gas with good heat conductivity, usually by the helium; it is possible that the central hole in the fuel pellet is absent, i.e. $R_{h}=0$. The heat, producing inside the volume of the fuel pellets due to the nuclear fission reaction, is transferred to the moving heat carrier thru the gaseous gap and the cladding of the fuel element; the heat carrier moves up along the axis of the fuel element from down-edge cap toward the upper-edge cap of the cladding. The difference between the average temperature inside the volume of the fuel pellets and the average temperature of the heat currier is about $1000 \mathrm{~K}$, but the difference between the average temperatures of the heat carrier on the level of the up- and down-edge caps is about $50 \mathrm{~K}$. As result of these circumstances and well-known the Fourier's Law of heat conduction, the heat flows along the longitudinal axis are significantly less than the heat flows along the radius of the fuel element with direction denoted as $r$ on the fig. 1; the circumferential heat flows are significantly smaller the radial heat flows too due to the longitudinal flows of the heat carrier are the almost symmetrical. Thus, all these circumstances allow to assume that the temperature of the fuel pellets is depended on the radial coordinate only at least in the central part of the fuel element far enough from the down and upper edges of the cladding. Further, the stationary temperature states only will be considered, and the well-known equation of heat conduction, which represent the temperature state of the ceramic nuclear fuel pellet in the fuel rod, can be wrote considering with the simplifying assumptions in cylindrical coordinates as follows [5]:

$$
\frac{d^{2} T}{d r^{2}}+\frac{1}{r} \frac{d T}{d r}=-\frac{Q}{\lambda_{f}}, \quad R_{h}<r<R_{f},
$$

where $T$ is the temperature in a point of the fuel pellet; $Q$ is the intensity of volume heat sources due to the nuclear fission reactions; $\lambda_{f}$ is the average heat conductivity of the ceramic nuclear fuel; $R_{h}$ and $R_{f}$ are the internal and external radii of the pellet (fig. 1).

Considering the thermal equilibrium on the inner surface $r=R_{h}$ and heat transfer on the outer surface $r=R_{f}$, the boundary conditions, for equation (1) defining the temperature state of the fuel pellet can be represented in the form [5]:

$$
\frac{d T}{d r}\left(R_{h}\right)=0, \quad-\lambda_{f} \frac{d T}{d r}=k\left(T\left(R_{f}\right)-T_{\mathrm{HC}}\right),
$$

where $k$ is the heat transfer coefficient from the fuel pellet to the heat carrier; $T_{\mathrm{HC}}$ is the temperature of the heat carrier.

It is possible to obtain the analytical solution of the heat conduction linear equation (1) considering with the boundary conditions (2):

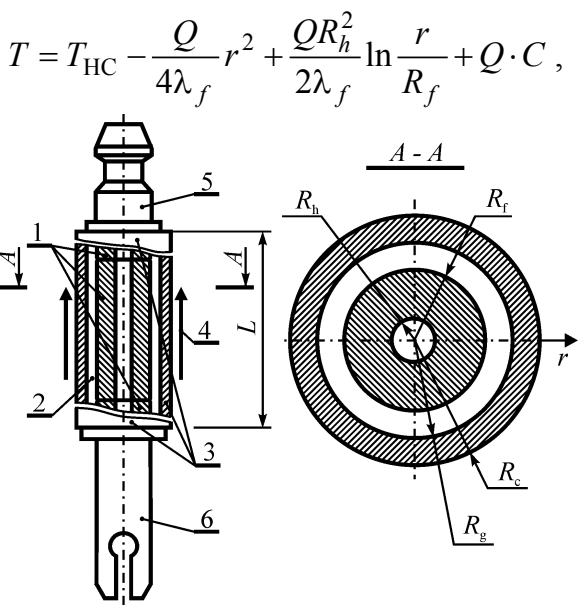

Fig. 1 - The typical scheme of the fuel element, containing the ceramic nuclear fuel:

1 - pellet of ceramic nuclear fuel; 2 - gaseous gap;

3 - cladding; 4 - moving heat currier;

5 - upper edge cap; 6 - down edge cap 
where $C=\frac{R_{f}^{2}}{4 \lambda_{f}}+\frac{R_{f}}{2 k}-\frac{R_{h}^{2}}{2 k R_{f}}$.

The average magnitude of the intensity of volume heat sources due to the nuclear fission reactions can be estimated as:

$$
Q=\frac{W}{n \pi\left(R_{f}^{2}-R_{h}^{2}\right) L},
$$

where $W$ is the heap power of the reactor; $n$ is the number of the fuel elements in the core of the nuclear reactor.

The heat transfer coefficient from the fuel pellet to the heat carrier is defined by the widths and the heat conductivities of the gaseous gap and the wall of the cladding, as well as the heat transfer from the cladding to the heat carrier [6]:

$$
k=\left(\frac{R_{f}}{\lambda_{g}} \ln \frac{R_{g}}{R_{f}}+\frac{R_{f}}{\lambda_{c}} \ln \frac{R_{c}}{R_{g}}+\frac{R_{f}}{\alpha R_{c}}\right)^{-1},
$$

where $R_{g}$ is the radius of the gaseous gap and $R_{c}$ is the radius of the cladding (see fig. 1); $\lambda_{g}$ is the heat conductivity in the gaseous gap and $\lambda_{c}$ is the heat conductivity of the cladding; $\alpha$ is the heat transfer coefficient between the cladding and the heat carrier.

Relations (3)-(5) represent the approximate quantitative estimation of the temperature state of the ceramic nuclear fuel in the fuel rod of nuclear reactor. These relations (3)-(5) give possibilities for researching influences on the temperature state of the fuel pellets such factors as the heat conductivity of the fuel, the heat conductivity of the gaseous gap, the heat conductivity of the cladding as well as the heat transfer from the cladding to the heat carrier.

\section{Results of researches the temperature state of ceramic nuclear fuel in VVER-1000}

Industrial power nuclear reactor VVER-1000 is the most widely used in the Eastern-European countries and is the basis for designing the next generation of power nuclear reactor for industrial purposes [7]. The parameters in relations (3)-(5), which are corresponded to the VVER-1000 nuclear reactor, are follows $[7,8]$ :

$$
\begin{gathered}
Q=3000 \mathrm{MW}, n=50856, L=3530 \mathrm{~mm}, T_{\mathrm{HC}}=583 \mathrm{~K} \\
R_{f}=3,765 \mathrm{~mm}, R_{g}=3,86 \mathrm{~mm}, R_{c}=4,55 \mathrm{~mm}, \\
\lambda_{f}=5 \frac{\mathrm{W}}{\mathrm{m} \cdot \mathrm{K}}, \lambda_{g}=0,3 \frac{\mathrm{W}}{\mathrm{m} \cdot \mathrm{K}}, \lambda_{c}=20,5 \frac{\mathrm{W}}{\mathrm{m} \cdot \mathrm{K}} \cdot(6)
\end{gathered}
$$

The As is well-known [9], the heat transfer coefficient between the cladding and the heat carrier is about

$$
33 \leq \alpha \leq 35 \frac{\mathrm{kW}}{\mathrm{m}^{2} \cdot \mathrm{K}} .
$$

Next, it will be considered separately the fuel pellets with $R_{h}=0$ and $R_{h}=1,15 \mathrm{~mm}$ [7].

It is understandable, that the decreasing the heat conductivities It is understandable, that the decreasing the heat conductivities on the nuclear fuel, the gaseous gap and the cladding will be lead to increasing the temperature of the fuel pellets. The quantitative estimations for influences of these heat conductivities on the temperature state of fuel pellet without the central hole are obtained for data (6), (7) using the relations (3)-(5) and are given on the fig. 2. It is understood, that the heat transfer between the cladding and the heat carrier is have some influence on the temperature state of the fuel pellets too. The quantitative estimations of this influence, obtained using the simplified assessments (3)-(5) for data (6) for fuel pellets without the central hole, are shown on the fig. 3 .

It is evidently, the central hole must have some influence on the temperatures of the fuel pellets. Quantitative assessments for influencing the central hole on the temperature state can be estimated using the results, presenting on the fig. 4 , which are obtained considering with the simplified assessments (3)-(5).

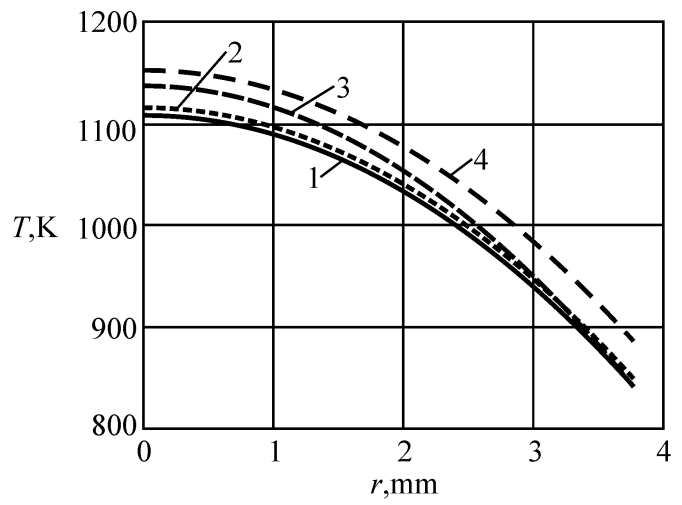

Fig. 2 - Temperature fields in the fuel pellets (6) without the central hole for $\alpha=35 \frac{\mathrm{kW}}{\mathrm{m}^{2} \cdot \mathrm{K}}$ :

1 - base values (6) of the heat conductivities; $2-\lambda_{c}=15 \frac{\mathrm{W}}{\mathrm{m} \cdot \mathrm{K}} ; 3-\lambda_{f}=4,5 \frac{\mathrm{W}}{\mathrm{m} \cdot \mathrm{K}} ; 4-\lambda_{g}=0,25 \frac{\mathrm{W}}{\mathrm{m} \cdot \mathrm{K}}$

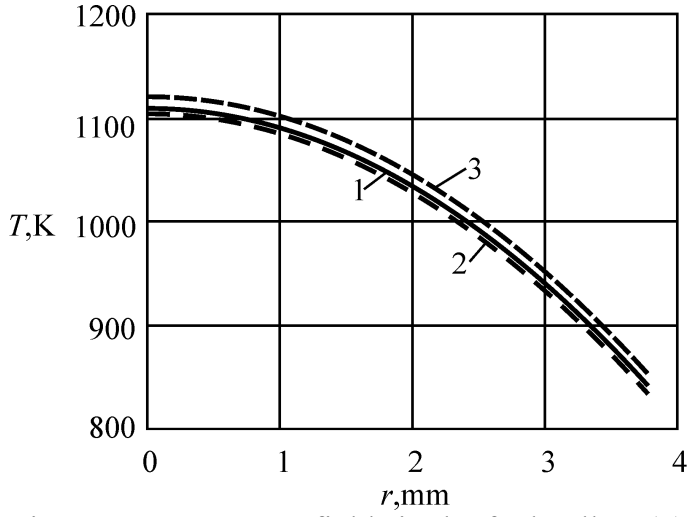

Fig. 3 - Temperature fields in the fuel pellets (6) without the central hole:

$1-\alpha=35 \frac{\mathrm{kW}}{\mathrm{m}^{2} \cdot \mathrm{K}} ; 2-\alpha=50 \frac{\mathrm{kW}}{\mathrm{m}^{2} \cdot \mathrm{K}} ; 3-\alpha=20 \frac{\mathrm{kW}}{\mathrm{m}^{2} \cdot \mathrm{K}}$ 


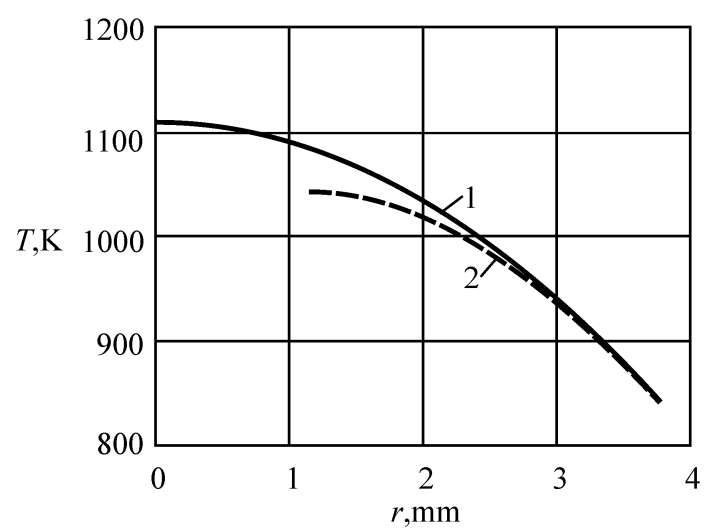

Fig. 4 - Temperature fields in the fuel pellets (6) without and with the central hole for $\alpha=35 \frac{\mathrm{kW}}{\mathrm{m}^{2} \cdot \mathrm{K}}$ :

$$
1-R_{h}=0 ; 2-R_{h}=1,15 \mathrm{~mm}
$$

The obtained results (see fig. 2-4) show that the approximate estimations (3)-(5), which are occurred from the simplified heat conductivity problem (1), (2), will can give the opportunities to understand the qualitative regularities of influencing the different factors on the temperature state of the pellets of the ceramic nuclear fuel in fuel rods of nuclear reactors. Besides, the approximate assessments (3)-(5) can gives also some imaginations about the quantitative magnitudes of the temperature in the fuel pellets.

\section{Discussing the results for temperature state of pellets of ceramic nuclear fuel}

The presented results (see fig. 2-4) about influencing of different factors on temperature state of pellets of nuclear fuel in fuel rods of nuclear reactors are corresponded for all well-known qualitative regularities and imaginations about the quantitative magnitudes, although all these results was obtained using the approximate assessments (3)-(5), based on the simplified mathematical model (1), (2). At the same time, these obtained results cannot be considered as the absolutely reliable assessments of the temperature state of the nuclear fuel pellets if fuel rods. The more reliable assessments of the temperature state of nuclear fuel pellets must be based on the most complicated mathematical models of the heat conductivity and the heat transfer in the area of the fuel rods to considering the assumptions more closely corresponding to the actual conditions during operating in the nuclear reactor core. Building such complicated mathematical models requires the sophisticated knowledge and approaches, which can be substantiated by benchmarking only. The approximate assessments (3)-(5) presented in this article can be used as the benchmarking for substantiated the most complicated mathematical models and approaches for estimating the temperature state of ceramic nuclear fuel in fuel rods of nuclear reactors. It is necessary to note, that the quantitative estimations of the temperature state of the fuel pellet inside the fuel rod are overvalued due to neglecting the axial heat flows, which must be directed outside the fuel elements pellets in the centre of the fuel rod, because the temperatures above and down theirs must be lower corresponding the axial distributions of the volume heat sources due to the axial distribution of the neutron field in the core.

Results about influencing the heat conductivities of the fuel element's materials on the temperature state of fuel pellets are shown that the heat conductivities of the gaseous gap and the cladding having influence on the average temperature only, but heat conductivity of the nuclear fuel having influence both on the average temperature and the difference between internal and external temperatures of the fuel pellet. The temperature state is especially sensitive to the heat conductivities of the nuclear fuel and the gaseous gap.

The heat transfer from the cladding to the heat carrier having influence on the average temperature of the nuclear fuel pellets inside the cladding of the fuel element. The central hole, made in the nuclear fuel pellets, leads to decreasing the temperature inside the pellet.

\section{Conclusions}

The approximate estimations for the temperature state of the ceramic nuclear fuel in cylindrical fuel rods of nuclear reactor is proposed in this article on the base of the simplified mathematical formulation of the heat conduction problem.

The approximate estimations for the temperature state of the ceramic nuclear fuel in cylindrical fuel rods of nuclear reactor is proposed in this article on the base of the simplified mathematical formulation of the heat conduction problem. It is shown that the proposed approximate estimations are corresponded to well-known qualitative regularities of influencing the parameters of fuel rods on the temperature state of the fuel pellets. At the same time, the quantitative estimations of the temperature state of the fuel pellet inside the fuel rod are overvalued due to neglecting the axial heat flows, which must be directed outside the fuel elements pellets in the centre of the fuel rod, because the temperatures above and down theirs must be lower corresponding the axial distributions of the volume heat sources due to the axial distribution of the neutron field in the core.

The main value of proposed approximate estimations is the opportunities of their using for benchmarking the most complicated mathematical models and approaches for assessment the temperature state of the ceramic nuclear fuel in fuel rods of nuclear reactors. Nevertheless on the base of the used simplified mathematical model it can be proposed to develop the improved approximate estimations considering with the axial heat flows corresponding with the axial distribu- 
tions of the volume heat sources due to the axial distribution of the neutron field in the core. It can be supposed, that the quantitative magnitudes will be estimated more accurate due to these improved assessments.

It is necessary to consider the temperature dependences of the heat conductivities of the nuclear fuel and the gas in the gap to obtain the more precisely assessments of the temperature state of fuel pellets inside fuel elements of nuclear reactors, because these heat conductivities having the most influencing on the temperature state of fuel pellets. This will be leaded to more complicate nonlinear differential equation of heat conductivity $[4,10]$.

\section{References (transliterated)}

1. Masterson R. E. (2017), Nuclear Engineering Fundamentals. A Practical Perspective, CRC Press, Boca Raton, FL, 961 p., ISBN 978-1-482-22149-7

2. Saha P. (2017), Nuclear Reactor Thermal-Hydraulics: Past, Present and Future, ASME Press, New York, 148 p., ISBN 978-0-791-86128-8.

3. Lamarsh J. R. and Baratta A. J. (2001), Introduction to Nuclear Engineering, Prentice Hall, Upper Saddle River, New Jersey, 783 p., ISBN 0-201-82498-1.

4. Yefimov A. V., Romashov Yu. V. and Chibisov D. O. (2018), "Modeling of Axisymmetric Heat Conduction in Compact Products of Ceramic Nuclear Fuel with the Temperature Dependencies of Thermophysical Characteristics", Bulletin of the National Technical University "KhPI". Series: System analysis, control and information technology, no. 21(1297), pp. 3-7, ISSN 2079-0023.

5. Hahn D. W., Özişik M. N. (2012), Heat Conduction, John Wiley \& Sons, Inc., Hoboken,718 p., ISBN 978-1-118-411285 .

6. Sarkisov A. A., Puchko V. K. (1989), Fizicheskiye osnovy ekspluatatsii yadernykh paroproizvodyashchikh ustanovok [The physical basis of the operation of nuclear steam plants], In Russian, Energoatomizdat, Moscow, 504 p., ISBN 5-283-03764-9.

7. Denisov V. P., Dragunov Yu. G. (2002), Reaktornyye ustanovki VVER dlya atomnykh elektrostantsiy [VVER reactor installations for nuclear power plants], In Russian, IzdAt, Moscow, 480 p., ISBN 5-86656-133-6.

8. Chirkin V.S. (1968), Teplofizicheskiye svoystva materialov yadernoy tekhniki: spravochnik [Thermophysical properties of nuclear engineering materials: a reference book], In Russian, Atomizdat, Moscow, $484 \mathrm{p}$.
9. Ovchinnikov F. Ya. and Semenov V. V. (1988), Ekspluatatsionnyye rezhimy vodo-vodyanykh energeticheskikh reaktorov [Operational modes of water-cooled power reactors], In Russian, Energoatomizdat, Moscow, 359 p., ISBN 5-28303818-1.

10. Yefimov A., Romashov Yu., Yesypenko T. and Chibisov D. (2018), "Numerical methods used for the solution of heat conductivity problems to study the temperature state of ceramic nuclear fuel. Bulletin of the National Technical University "KhPI". Series: Power and Heat Engineering Processes and Equipment, no. 13(1289), pp. 33-36, ISSN 2078-774X, doi: 10.20998/2078-774X.2018.13.06.

\section{References}

1. Masterson R. E. Nuclear Engineering Fundamentals. A Practical Perspective. Boca Raton, FL: CRC Press, 2017. 961 p. ISBN 978-1-482-22149-7

2. Saha P. Nuclear Reactor Thermal-Hydraulics: Past, Present and Future. New York: ASME Press, 2017. 148 p. ISBN 9780-791-86128-8.

3. Lamarsh J. R. and Baratta A. J. Introduction to Nuclear Engineering. Upper Saddle River, New Jersey: Prentice Hall, 2001. 783 p. ISBN 0-201-82498-1

4. Ефимов А. В., Ромашов Ю. В., Чибисов Д. А. Моделирование осесимметричной теплопроводности в компактных изделиях керамического ядерного топлива с учетом температурных зависимостей теплофизических характеристик. Bicник Національного технічного університету «ХПІ». Серія: Системний аналіз, управління та інформаційні технології. 2018. № 21(1297). C. 3-7. ISSN 2079-0023.

5. Hahn D. W., Özişik M. N. Heat Conduction. Hoboken: John Wiley \& Sons, Inc., 2012. 718 p. ISBN 978-1-118-41128-5.

6. Саркисов А. А., Пучко В. К. Физические основы эксплуатаиии ядерных паропроизводящих установок. Москва: Энергоатомиздат, 1989. 504 с. ISBN 5-283-03764-9.

7. Денисов В.П., Драгунов Ю.Г. Реакторные установки ВВЭР для атомных электростанций Москва: ИздАТ, 2002. 480 c. ISBN 5-86656-133-6.

8. Чиркин В. С. Теплофизические свойства материалов ядерной техники: справочник. Москва: Атомиздат, 1968. 484 с.

9. Овчинников Ф. Я., Семенов В. В. Эксплуатационные режимы водо-водяных энергетических реакторов. Москва: Энергоатомиздат, 1988. 359 с. ISBN 5-283-03818-1.

10. Ефимов А. В., Ромашов Ю. В., Есипенко Т. А., Чибисов Д. А. Численные методы решения задач теплопроводности для изучения температурного состояния керамического ядерного топлива Вісник Національного технічного університету «ХПI». Серія: Енергетичні та теплотехнічні прочеси й устаткування. 2018. № 13(1289). С. 33-36. ISSN 2078-774X. doi: 10.20998/2078-774X.2018.13.06.

Received (поступила) 15.02.2019

Відомості про авторів / Сведения об авторах / About the Authors

Ромашов Юрій Володимирович (Ромашов Юрий Владимирович, Romashov Yury) - доктор технічних наук, доцент, Національний технічний університет «Харківський політехнічний інститут», професор кафедри парогенераторобудування, Харківський національний університет імені В.Н. Каразіна, професор кафедри прикладної математики; м Харків, Україна; e-mail: yu.v.romashov@gmail.com, ORCID: https://orcid.org/0000-0001-8376-3510.

Чібісов Дмитро Олексійович (Чибисов Дмитрий Алексеевич, Chibisov Dmytro) - магістр, аспірант кафедри парогенераторобудування, Національний технічний університет «Харківський політехнічний інститут»; м Харків, Україна. 